日レ歯誌 J. Jpn. Soc. Laser Dent. $16: 134-139,2005$

\title{
Nd:YAG レーザーの臨床応用
}

\author{
和 賀 正 明 \\ 旭川歯科クリニック・秋田県開業 \\ (受付：平成 17 年 4 月 15 日，受理：平成 17 年 7 月 22 日)

\section{Clinical Application of Nd:YAG Laser}

\author{
Masaaki WAGA \\ Asahikawa Dental Clinic
}

(Received April 15, Accepted for Publication: July 22, 2005)

\begin{abstract}
Recently, laser beams are increasingly being used as a useful tool in dental practice.
In this study, the author used two type of high peak pulse Nd:YAG laser devices (Medical Science Co., Tokyo and Altech Co., Tokyo).

More than 30,000 patients have undergone laser treatment successfully in our clinic.

There are five characteristics of clinical-application lasers:

1) Processing the tip of the optical fiber with $\mathrm{TiO}_{2}$

2) Using $\mathrm{TiO}_{2}$ as a reaction mediator between laser beam and dental tissues

3) Selective conditions for optimum laser treatment

4) Development of technique for laser irradiation

5) Cooling system for hard and/or soft tissues

In this report, the author describe the minimal invasive treatment of incipient caries, treatment of infected root canal, serious case of periodontitis, and marsupialization of impacted molar tooth.

The author also discuss the role of $\mathrm{TiO}_{2}$ in helping to reduce the excess reflectivity and absorbability of the laser beam on dental tissues.

(J. Jpn. Soc. Laser Dent. $16: 134 \sim 139,2005$ Reprint request to Dr. WAGA)
\end{abstract}

Key words $=$ Processed fiber, $\mathrm{TiO}_{2}$, Nd:YAG laser

キーワード=ファイバー加エ, 酸化チタン反応剂, Nd:YAGレーザー

\section{緒言}

レーザーは, 現在の歯科臨床において, 高頻度に使用さ れる有効な医療機器である。Nd:YAGレーザーは, 波長 $1,064 \mathrm{~nm}$ の近赤外光であり, レーザーの発振媒体はイット

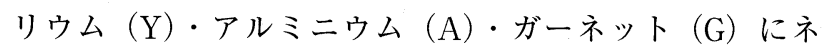
オジウム $(\mathrm{Nd})$ が添加されたものである。 Nd:YAGレー ザーに関する研究は 1960 年代に眼科 1)での応用が始まり, その後各診療科で広く用いられるに至った。わが国の歯科 領域では初期う蝕の進行阻止療法が 1991 年に高度先進医 療として厚生省から承認された ${ }^{2)}$ 。

Nd:YAG レーザーには，連続波とパルス波があり，パ
ルス波は, 超音波 Q-スイッチ付 (AOQ-sw), ノーマルパ ルス, ジャイアントパルス（ハイピークパルス）の 3 種の 発振形式のものがある。当医院は 3 台のハイピークパルス Nd:YAG レーザー（メディカルサイエンス社製 図 1, ア ルテック社製 図 2) を用い, 現在まで延べ約 3 万人の歯 科疾患患者に安全かつ有効に応用している。

このレーザーを臨床に使用する際のポイントは, (1)ファ イバー先端の加工(2)反応剤（酸化チタン）使用(3)最適な照 射条件の選択(4)照射手技(5)照射対象の冷却などにある。こ れらを活用し初期踼蝕治療, 感染根管処置, 重度歯周疾患 への応用，埋伏歯の開空術等の実症例とその有効性につい て報告する。なお，Nd:YAGレーザーを照射する際，熱 
的にも化学的にも安全な酸化チタンを反応剂として用い る。これは, レーザー光の組織からの反射や内部への到達 を減らし, かつレーザー光の吸収効率を上げる目的で使用 している。

\section{本機の特性}

性能と特徵は次のと打りである。

波長 $1,064 \mathrm{~nm}$ ，ストリーク（アルテック社）のパルス幅

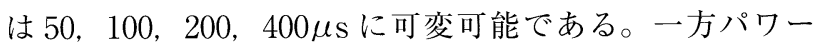
パルス（メディカルサイエンス社）は $400 \mu \mathrm{s}$ である。両 機の最大出力は $13,5 \mathrm{~W}$, パルスレート $1 \sim 15 \mathrm{pps}$, 光 学系石英ファイバーを使用し, その同軸上で空冷と水冷及 び先端加工が可能である。

\section{ファイバー加工について}

とりわけ日常臨床によく遭遇する小窩裂溝, 隣接面, 歯 周ポケット, 感染根管等のように, 解剖学的に極めて狭小 な部位へのレーザー照射を必要とする場合, 対象とする病 巣は前方照射方向に存在するよりはむしろ通常側方に散在 している。したがって側方照射に重点を置くことが重要と なる。側方照射には直進方向にのみ出る光ファイバー （bare fiber）でなく先端加工を施すことにより光を全周囲 方向に出すことが出来る先端加エファイバー（processed fiber）を使用する（図 3-1）。この加工は Nd:YAG レーザー においては極めて容易である。因みに, ポット加工は, 加 工ポット内で, 約 $30 \mathrm{mg}$ の圧接下で照射エネルギー $500 \mathrm{~mJ}$ 繰り返し速度 10pps（以下 500mJ-10pps，パネル表示）の 照射条件で 2 秒間すると得られる。(図 3-2, 3-3) 加工さ れたファイバー先端から照射されるレーザー光は, 全周囲 方向へ照射され，その分直進光が減衰する ${ }^{3,4)}$ 。

加工ファイバーの特徵としては, (1)組織の切開には直進 方向のみのレーザー光では不可能であるが, 先端加工に よって全周照射が可能になる。(2)小窝裂溝や歯周ポケット の処置にも, 周囲方向への照射が不可欠であるが, ファイ バー加工によって可能となる。(3)加工前直進方向へ $4.0 \mathrm{w}$ の先端出力は加工後には $1.4 \mathrm{w}$ に減弱 $(65 \%$ の減）させる ことができる。(4)軟組織切開の病理組織像では, 炭化層, 凝固層とも僅少である。(5)接触端子表面で熱変換が行われ るのでファイバーの先端に触れている組織にのみ反応し周 囲組織へ熱損傷が及ぶことは少ない(6)空冷ないし水冷下に おいても機能するなどが挙げられる。

\section{臨床応用}

\section{1）初期䠛蝕の予防処置への応用}

(1) 症例

患者は 13 歳女性, 主訴は, 上顎前歯の白濁, 凹凸感と 冷水痛である。視診によると, 上顎前歯の歯澒部に, 白濁
があり，右側犬歯と左側側切歯には実質欠損があった（図 4-1）ダイアグノデント（以下 Dd 值と記す）により図中

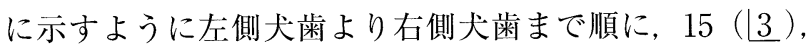
$52(\lfloor 2) ， 11(\lfloor 1) ， 6(\underline{1}) ， 8(\underline{2\rfloor}), 27(\underline{3}\rfloor)$ の測定 值を示した。

\section{(2) 照射術式}

レーザー光の吸収を促進させる為に反応剤として, タン ニン酸セメント（HYC）を塗布した。ファイバー加工後, 照射条件は $200 \mathrm{~mJ}-10 \mathrm{pps}$, 歯面より，0.5mm の距離にて 1 点に集中しないよう, ファイバーを速やかに動かしながら 刷掃するように照射を行なった。さらに, 光と同軸上から のエアー放出冷却により, 熱の蓄積を避けた。 来院時一 回の処置として 1 歯に 200J を目安に, $3+3$ の 6 歯に対

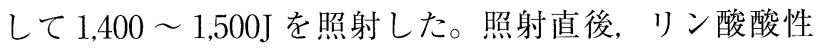
フッ素溶液 $(\mathrm{APF})$ を塗布した。

(3) 成績

2 ヶ月経過後, 白濁の消失や改善が認められ, 歯冠歯澒 部表面の凹凸感が粗造感に変化した。Dd 值は，5（|3）, $8(\lfloor 2) ， 4(\lfloor 1) ， 1 （ \underline{1}) ， 5 （ 2\rfloor) ， 8 （ \underline{3}\rfloor ）$ と著明に低 下している。左側側切歯扔よび右側犬歯の実質欠損は拡が らず，減少傾向にあると思われる（図 4-2）。5 ケ月後の状 態も良好である ${ }^{4)}$ (図 4-3)。

図 5-1，5-2，5-3 は，4 年のフォローアップのケースで あるが, このケースを含め, 長期にわたり安定してい る ${ }^{6)}$ 。

\section{(4) 考察}

以上の臨床結果より，レーザー照射とフッ化物の併用に より，従来法より短期間に(1) 耐酸性の付与 (7) (2) フッ素の 取り达みの増強(3)初期う蝕の再石灰化(4)感染歯質の殺菌な どから予後良好になったと思われる。切削を目的とせず病 変部組織のみの選択的除去による最小浸襲処置を可能にし たと思われる。

\section{2）歯内療法への応用}

(1) 症例

患者は 55 歳女性, 上顎右側側切歯の根尖部の圧痛自発 痛, 打診痛のため来院した。X 線診査の結果, 根尖部に拇 指頭大の歯根囊胞が認められ, 根管治療時に渗出液がみら れた（図 6-1）。

\section{(2) 照射術式}

通常の根管治療を行った後, レーザーによる治療を行っ た。通法に従いファイバー加工後, 600mJ-3pps（1.7W） で $1 \sim 2$ 秒の照射を 1 週間隔にて 3 回行った。術式は, 根 管内に $3 \%$ 酸化チタン乳液を反応剂として満たし, 根尖 $3 \mathrm{~mm}$ からファイバーを引き上げながら照射した。

\section{（3）成績}

根管充填後（図 6-2）, 及び術後 6 力月後（図 6-3）のデ ンタル X 線写真像を示す。根尖部透過像の消失が早期に 


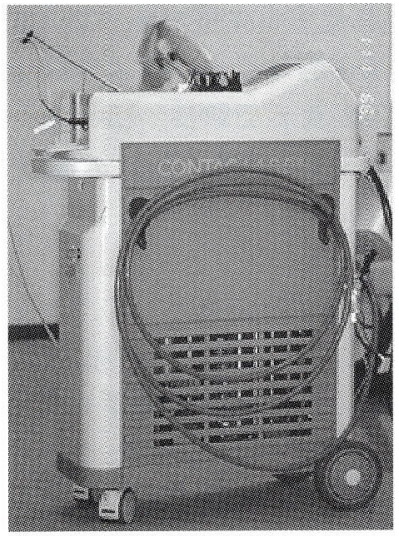

図1メディカルサイエ ンス社製 パワー パルス

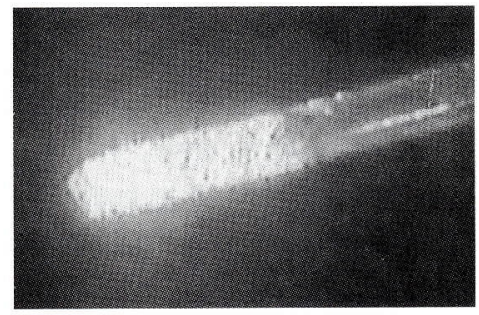

図 3-1 プロセスドファイバー

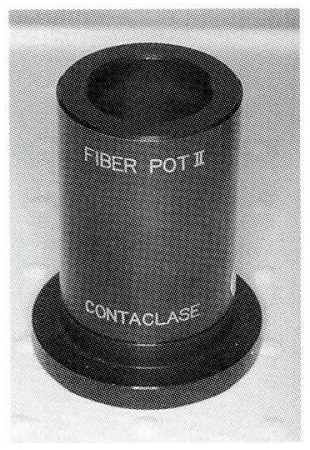

図 3-2 加工ポット

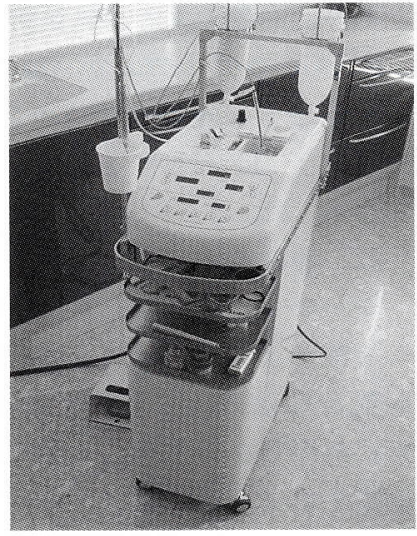

図 2 アルテック社製 ストリーク

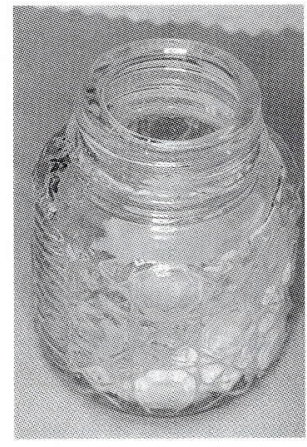

网 3-3 チタンポット

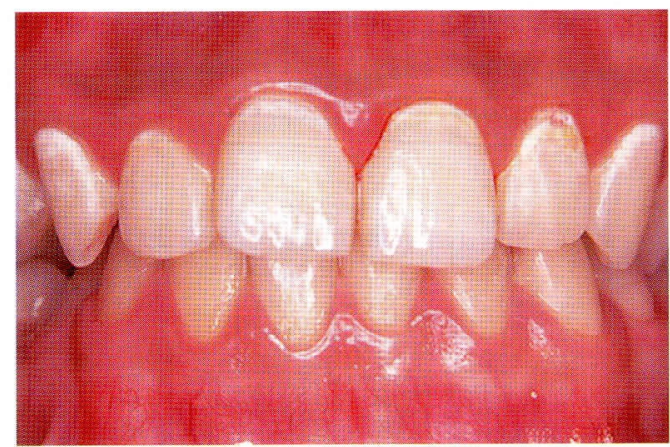

図 4-1 術前の前歯唇面観

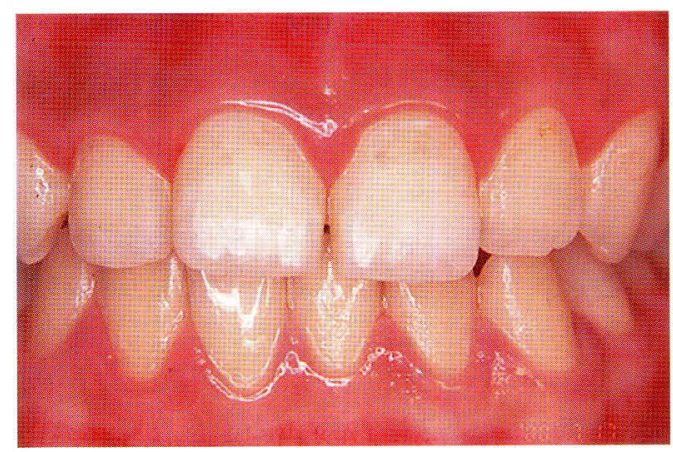

四 4-2 照射 2 力月後

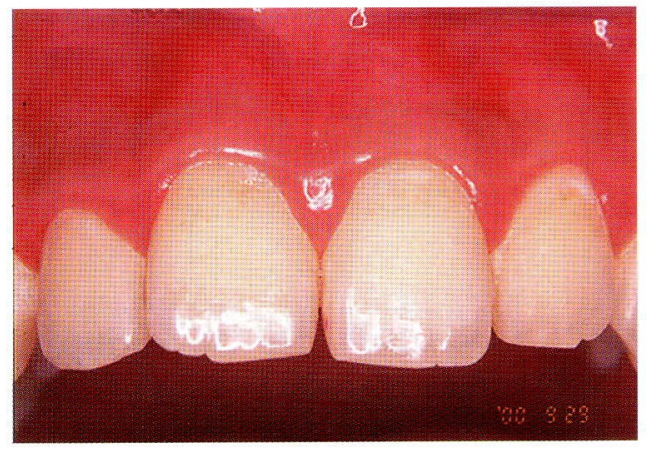

図 4-3 照射 5 力月後

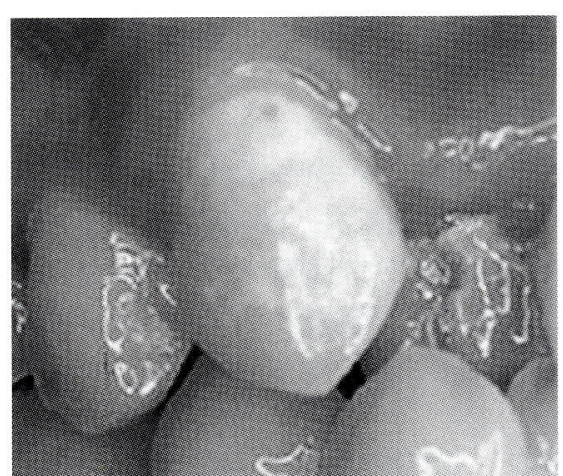

図 5-1 術前の前歯唇面観

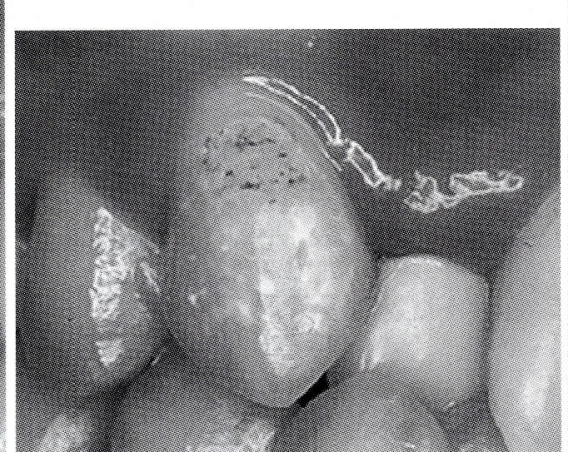

図 5-2 照射直後

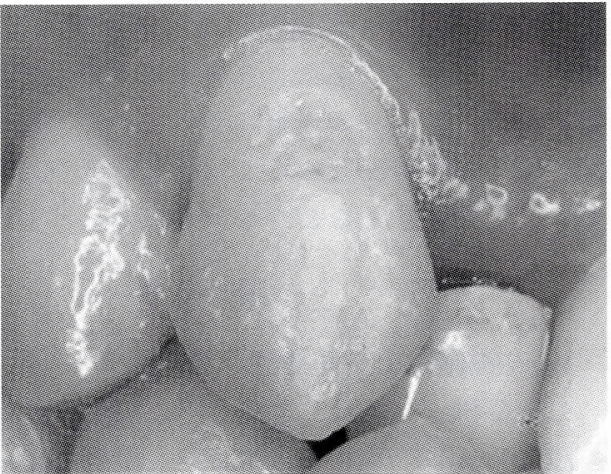

図 5-3 照射 4 年後 


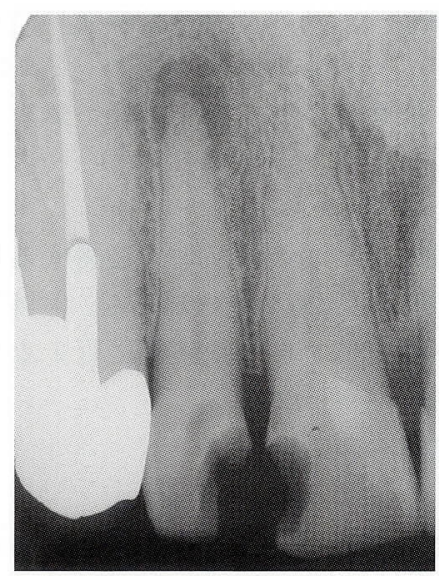

図 6-1 術前のX 線写真

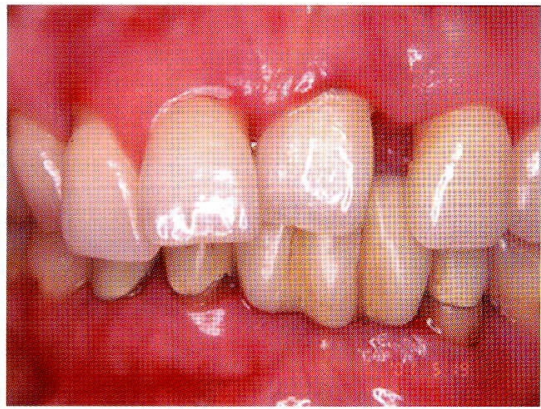

図 7-1 術前の前歯唇面観

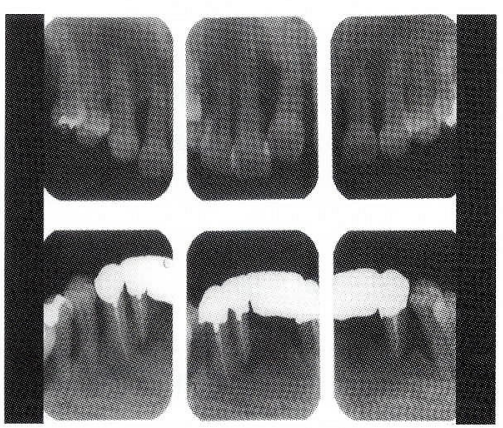

図 7-3 初䛦時の X 線写真

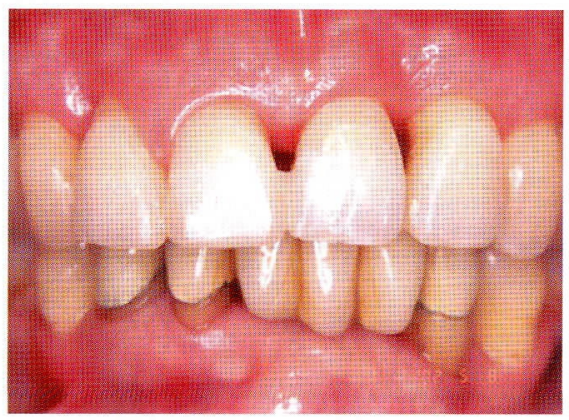

四 7-4 1 年 3 力月後の前歯唇面観

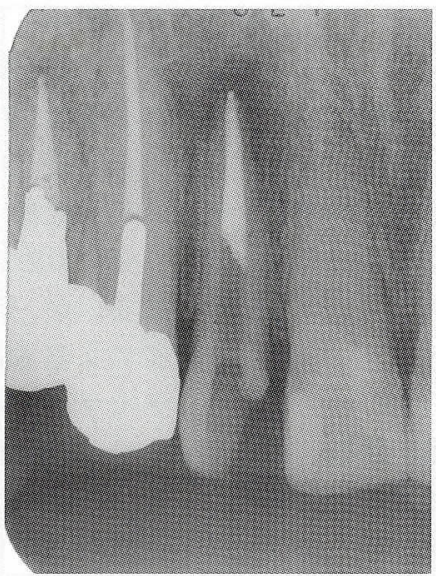

図 6-2 根管充填後の X 線写真

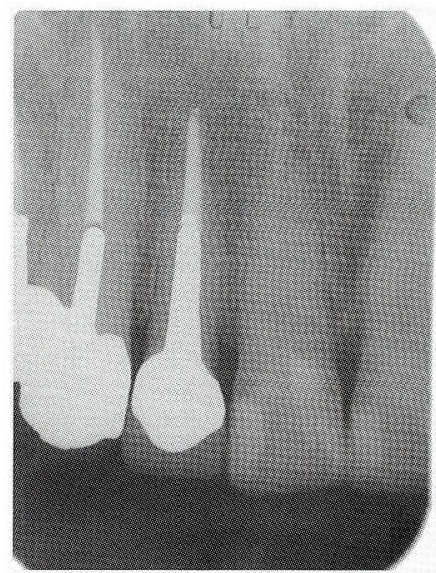

図 6-3 6力月後の X 線写真

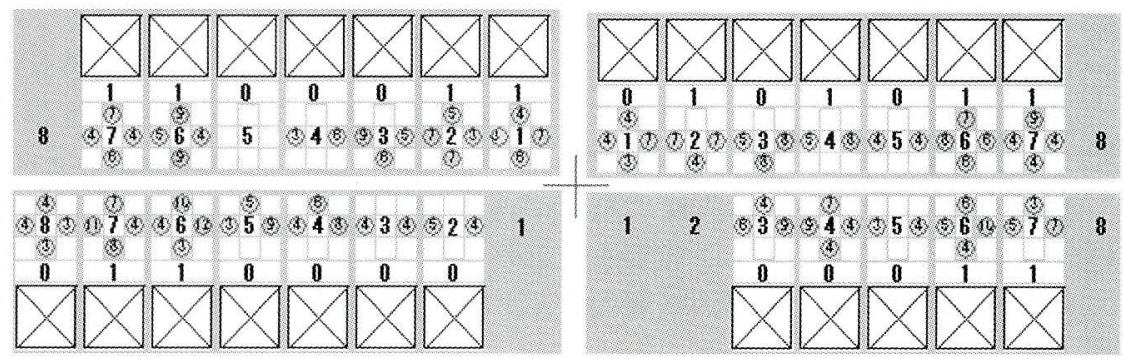

図 7-2 初診時の歯周精密検查

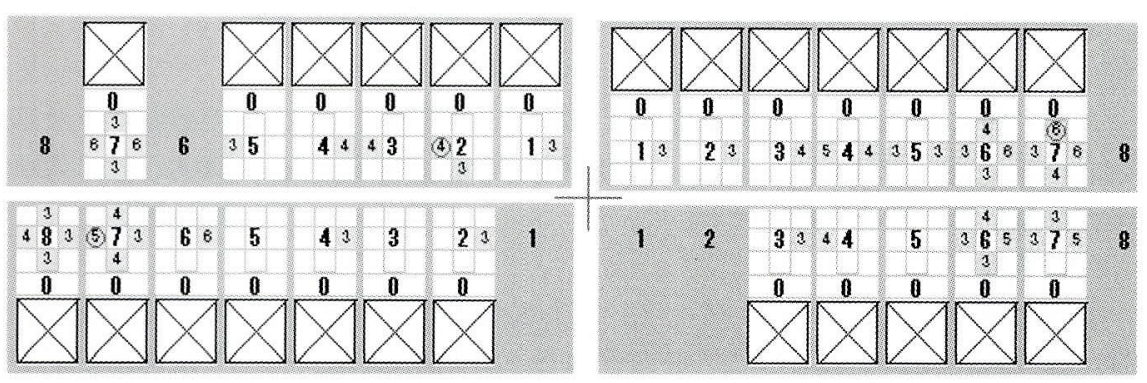

図 7-5 1 年 3 力月後の歯周精密検查 
認められ，臨床症状も良好であった。

(4) 考察

難治性の感染根管治療についても従来の根管治療法に加 えレーザーが有効であると思われる。この場合レーザー光 は前方のみならず周囲方向へも照射され，反応剂を併用す ることにより安全かつ有効な処置を可能にしていると考え られる。

\section{3）歯周疾患への応用}

(1) 症例

患者は 49 歳女性で全顮にわたる冷水痛，歯の動摇，お よび歯肉の自発痛のため来院した（図 7-1）。特記すべき既 往歴, 現病歴はないが, 歯科治療に対しての恐怖感と精神 面の不安定さがあった。

ウォーキング法による 4 点法のプロービングデプスの測 定では, $4 \mathrm{~mm}$ 以上 39 箇所, $7 \mathrm{~mm}$ 以上は 24 箇所, BOP は 76 箇所プラークインデックス $60 \%$ と重症であった（図 7-2)。デンタル X 線写真から前歯部に扔いて（図 7-3），水 平性の骨吸収と楔状骨欠損が認められた。

（2）治療術式

プラークコントロール，PMTC，スケーリング後，レー ザーによる歯周ポケット掻爬術を行った。

通法によりファイバー加工後, $500 \mathrm{~mJ}-9 \mathrm{pps}$, 直進方向 の出力 $1.4 \mathrm{~W}, 3 \%$ 酸化于タン乳液を反応剂として使用, ファイバーと同軸のエアー冷却を併用しながら間歇照射を 行った。

照射方法はポケット底から $1 \mathrm{~mm}$ 上方に離しながら ウォーキング法のプロービングをする場合のように側方移 動させながら照射を行った。さらに $1 \mathrm{~mm}$ ずつ歯冠側に移 動し， 3〜4歯の対象ポケット内の全面にトータルジュー ル（パネル表示） 500J 前後を目安として 20 分ほどの時間 をかけて照射を行った。因みに500Jを連続して照射した 場合の所要時間は 1 分 40 秒ほどである。ポケットの内縁 上皮付着部を傷つけないことやファイバーを同一部位に止 めないで照射することも注意すべきポイントと考えられ る。

照射にあたっては歯周ポケット内壁の上皮に接触するよ うな角度でファイバー側面からの照射光を使い，ポケット 内縁上皮扔よび炎症性結合組織の蒸散と除去を行った。

次いで，エアースケーラーと手用キュレットでSRPを 行い，ポケット内のデブリスや歯石などを洗浄し根面セメ ント質の污れを除去し，根面を滑沢にした。その後ボスミ ンを含んだガーゼにより圧迫後, 処置を終了した。翌日, またそれ以降の予後も良好であった。

\section{（3）成績}

初診より約 1 年 3 カ月後, レーザーによる歯周基本治療 は，週一度，左側上顎より $4 \sim 6$ 歯ずつ 3 ヶ月間行った。 炎症がコントロール出来た段階で，矯正処置を併用してい
る（図 7-4）。図は初診時と, 1 年 3 カ月後のプロービング デプス等の変化である。 $4 \mathrm{~mm}$ 以上は 21 箇所, $7 \mathrm{~mm}$ 以上 は 0 箇所，BOPは 3 箇所，プラークインデックスは $40 \%$ であった（図 7-5）。

\section{(4) 考察}

全ての歯周病の症例がこの症例と同様に改善するわけで はないが，お抢よそ良好な結果を認めている。非外科的処 置によるSRPをより確実に，かつ低侵襲に行えるアクセ スセラピーとして有効と思われる。

\section{4）埋伏歯の開空処置への応用}

(1) 症例

患者は 10 歳男子で歯列不正及び下買第 1 大臼歯の萌出 遅延を主訴として来院した。近医で矯正治療を行っている が, 歯列が改善していない。初診時の口腔内写真である (図 8-1)。

(2) 照射術式

$\sqrt{6}$ の未萌出歯の開空処置を行った。X 線診査の結果, 粘膜下 $7 \mathrm{~mm}$ の哚さに 6 が確認された（図 8-2）。

局所麻酔を行い, 通法に従いファイバー加工後, 切開開 始点に $3 \%$ 酸化チタンを反応剂として塗布, エアー冷却 を使用しつつ, $900 \mathrm{~mJ}-10 \mathrm{pps}$ （直進方向出力 $2.2 \mathrm{~W}$ ）にて 粘膜切開を行った（図 8-3）。

手技としては，加工ファイバーをハンドピースより長め にだし，45 度の角度からファイバー側面を使って，軽く 接触させ，ファイバーのしなりを利用しながら切開を行っ た（図 8-5）。処置当日に，ブラケットを装着した（図 $8-4)$ 。

(3) 結果

短時間にて, 切開が可能であり, 炭化層, 出血, 疼痛も 少なく治癒も良好な経過を辿った。われわれのラットの舌 を加工ファイバーにて切開した動物害験では舌の病理組織 像は炭化層, 凝固層とも僅少であり, 組織へのダメージは 軽微で早期な治癒が認められた ${ }^{4)}$ (図 8-6）。

(4) 考察

加エファイバー, 酸化チタン反応剂等の相互作用によ り, 軟組織の切断と即時凝固を可能にした。高い止血効果 により，外科処置直後のブラケット装着が可能となった。

\section{まとめ}

ファイバー先端加工により, 上記の如く日常臨床で, 初 期龇蝕の予防処置はもとより, 症例として頻度の高い小㸗 裂溝う蝕, 歯周ポケット掻破, 感染根管処置, 軟組織の切 開処置等に対するレーザー治療を，安全かつ有効に行うこ とが可能となった。この場合，ハイピークパルス Nd:YAG レーザーを使用するが，処置効率をあげるために酸化チ夕 ン反応剂の応用が推奨される。今後は更に至適パルス幅や 照射術式等を検討する所存である。 


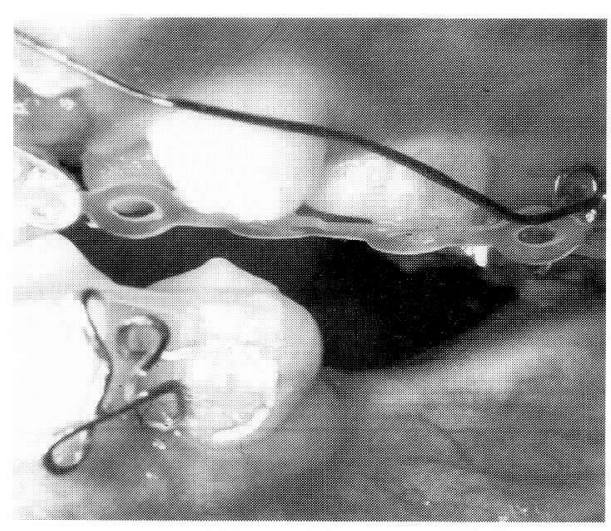

図 8-1＼cjkstart初診時の側面観

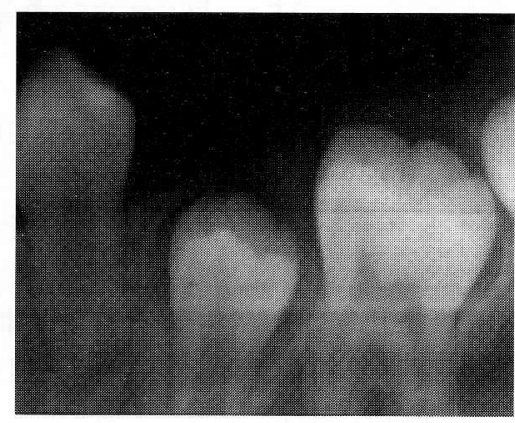

図 8-2 初診時の X 線写真

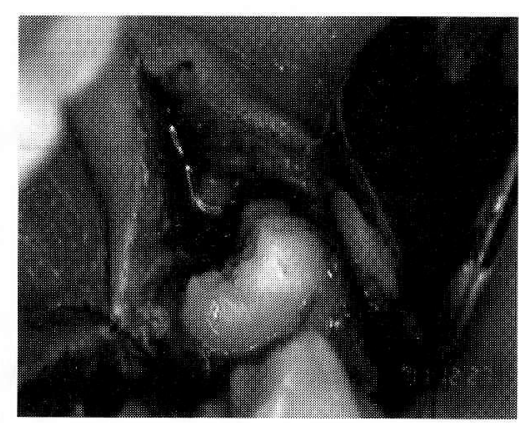

四 8-3Ｎd:YAGレーザーによる切開直後

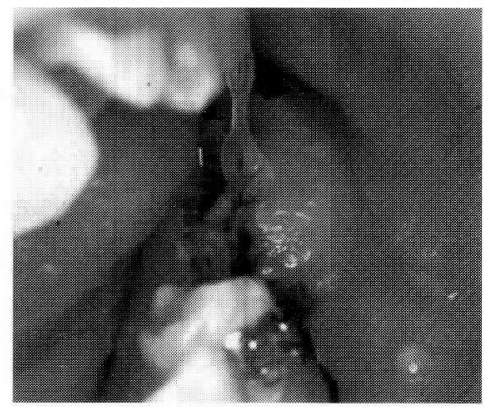

図 8-4 処置翌日

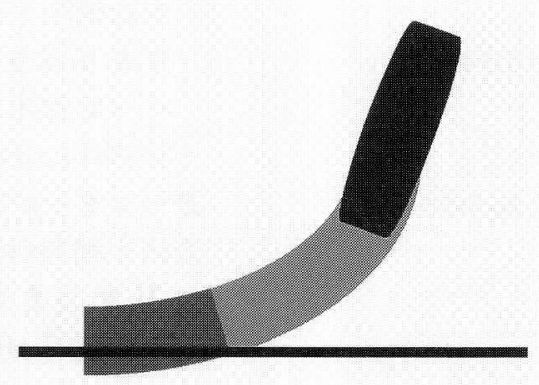

四 8-5 ファイバーの接触方法

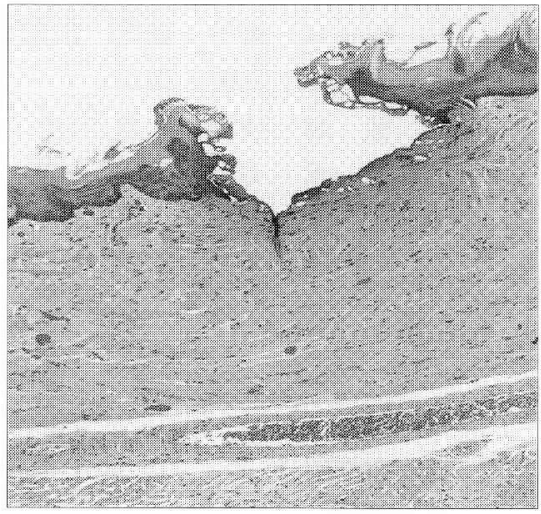

図 8-6 ラット舌のプロセスドファイ バーによる切開像

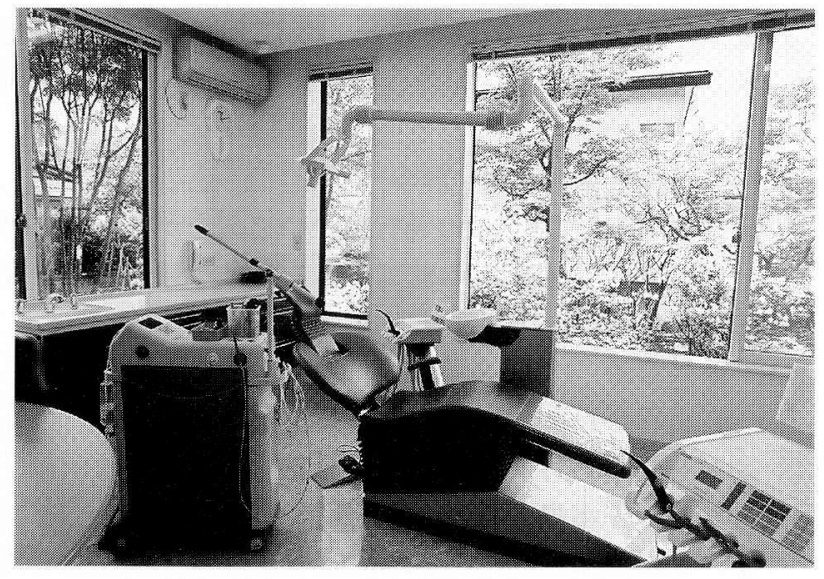

図 9 診療室内観

現在の旭川歯科クリニックは, スタッフ 17 名, ユニッ ト 9 台, レーザー 7 台で日常の診療を行っている。図 9 は 診療室の内観である。安全面を考虑しかつレーザー診療を 行い易くする為，充分な広さをもった個室形式をとってい る。今後レーザーはますます㐘科臨床に扔いて応用される ことが多くなるであろう。したがって更なる研究及び診療
室での安全性を充分に認識した臨床応用を重ねながら, Nd:YAG レーザーが一層有効な装置として発展する事を 望んで止まない。

\section{文献}

1) Zaret, M.M., Breinin, G.M., Schmidt, H., Ripps, H., Siegel, I.M., and Solon, L.R.: Ocular Lesions produced by an optical maser (Laser). Science, 134: 1525-1526, 1961.

2）森阔俊夫：Nd:YAGレーザーによる初期う蝕の進行阻止療 法. 高度先進医療, $7: 207,1995$.

3）斉藤陽一, 斉藤泰子：先端加エファイバーの軟組織への影 響. 森阙俊夫編, 別冊 Quintessence 歯科用レーザー 21 世紀 への展望・パート1. 東京, 2001, クインテッセンス出版. 192-193.

4）杉原成良, 神谷 誠, 和賀正明：Nd:YAGレーザー用光ファ イバーの $\mathrm{TiO}_{2}$ による先端加工. 日レ歯誌, 14:25-31. 2003.

5) 和賀正明, 神谷 誠, 杉原成良：ハイピークパルス Nd:YAG レーザー照射による初期萭蝕の最小侵襲処置について。 日レ 柬誌，14：131-138，2003.

6) 和賀正明：ハイピークパルス Nd:YAGレーザー照射による 初期齵蝕の最小侵襲処置と経年観察, 森岡俊夫編, 別冊 Quintessence 秚科用レーザー 21 世紀の展望パート2. 東京, 2004, クインテッセンス出版, 12-15.

7）山田恵子，桜井 聡, 神山紀久男：人工的 初期脱灰エナメ ル質へのレーザー照射とフッ化物塗布併用による鬹蝕抑制効 果に関する実験的研究. 小览㐘誌， 26：732-742， 1998. 